\title{
HYDRO-ELECTRIC WORKS AND NATURE
}

\author{
By The Rt. Hon. Lond Huncomb, G.C.B., K.B.E.,
} President of the Society for the Promotion of Nature Reserves

The most striking and perhaps far-reaching of all the human interferences with Nature witnessed in the present century is that represented by the widespread lowering of water-tables, the correction and regulation of the regime of rivers and the construction of large dams and new artificial lakes, most of which are constructed for the purpose of generating clectricity.

The adverse effects of this interference with the soil and with vegetation and wild life of all kinds are painfully obvious to biologists and naturalists, who are able to realize and to assess the scientific interest of the areas which hydro-electric and similar works are bound to modify profoundly and which too often they devastate in a biological sense.

But the loss of this interest and of these values is not the concern only of specialists in the various sciences. It concerns all those who are able to appreciate the meaning of the pageant of nature and to find intellectual and aesthetic pleasure in its contemplation. It concerns equally the humblest lovers of their "dear native regions", and the tourist or the mountaineer who is injured by the defacement of familiar or famous landscapes. All of them have reason to join the ranks of those who are now endeavouring, late in the day, to protect and to conserve Nature.

It is, of course, fair to recognize that those who construct these works may claim to bring some gains into the account. An artificial lake or reservoir often adds interest to the landscape and thus compensates in part for the submergence of the valley floor, if it was not the habitat of elements of special importance in the flora or fauna of the country. New forms of aquatic life may develop under conditions worthy of study. Or new sanctuaries may be provided, as has been done, for example, by the reservoirs on which, within half an hour's reach of the centre of London, it is possible to see ten or twelve kinds of diving and surface-feeding ducks, some of them in large numbers, on any winter's day.

On balanec, unfortunately, the biological losses are bound to be great. Nevertheless the protectionists accept the necessity of a wise exploitation of natural resources in the service of mankind and of further development of water-power in particular, and those whose special concern it is to protect nature do not take up an intransigeant or impracticable position in this matter. They have rarely felt compelled to offer out-and-out resistance 
to schemes of such development, although they have been bound to do so where, for example, the inviolability of a declared national park is threatened with invasion, habitats of exceptional and possibly unique and irreplaceable scientific value would be destroyed, or some feature of outstanding national beauty defaced.

The International Union for the Protection of Nature believes that much can be done to avoid such destruction and loss by better and fuller understanding between the engineers responsible and competent biologists. It is to this possibility that the Union has devoted attention in recent years and upon which it is concentrating much effort. The series of papers read at the Caracas meeting in $1952^{1}$ illustrated the extent and range of the damage to wild life, and to natural resources, which has occurred in the last few decades and is still being inflicted by uncontrolled developments in many parts of the world. Too often the engineer has proceeded in complete ignorance of the biological consequences of his operations and in disregard of any consideration except the provision of the maximum power at what appears at the moment to be the lowest expenditure of money.

Fortunately there have been exceptions, and it is gradually becoming recognized that the greatest economic good will not, in the long run, be secured by destroying for some temporary advantage, natural resources which, if carefully conserved and rightly managed, would renew themselves indefinitely. Forests are an example of such resources.

The policy of the Union is, therefore, first to urge Governments to be vigilant in safeguarding absolutely those areas, such as national parts and reserves, which have been set aside for conservation by acts of public policy. This means a clearer recognition and a more whole-hearted acceptance of scientific values and the claims of Nature, as entitled in their own right to high priority in the scale of national interest ; and not merely to be taken into account after every more immediate human demand, however short-sighted, has been satisfied.

Next the. Union urges that all organizations, governmental or private, engaged in constructing hydro-electric works, should, as part of their normal procedure, avail themselves of the knowledge which is to be gained by research into the effects of a disturbance of the natural equilibrium and of the flora and fauna, which their projects are likely to cause. It is also important that there should be an exhaustive study of all the

1 Now published in a volume "IIydroelectricity and the Protection of Nature" to be obtained from the Union's Onice, 31 Rue Vautier, Brussels. 
possible alternatives before any particular scheme is advanced, so that there may be time to select that which is likely to be least injurious biologically.

In some countries these ends are already attempted and partially achieved. To take two examples ; in the United States and in Switzerland there is great vigilance and useful intervention on behalf of Nature and wild life, with varying success. In Great Britain we have established under royal charter the Nature Conservancy which is responsible to a Committee of the Privy Council and to the Lord President of the Council, a senior Minister who is able to represent the interests of science and the Conservancy at the highest ministerial levels.

The Conservancy itself owns and manages, or otherwise controls, many important nature reserves and is able to designate other sites as areas of special scientific importance by reason of their floral, faunal, geological or physiographical interest. When such an area has been designated the responsible authority must consult the Conservancy before altering its use. The Conservancy is also consulted by all departments of the Government whose activities in any way conflict with or relate to its functions. Hydro-electric works fall within this province and the authorities themselves have been willing to recognize the need for biological advice.

Much good work was done by the North of Scotland HydroElectricity Board in preserving and even improving means of passage for migratory fish and it is hoped that members of the Union will themselves be able to inspect these devices when they visit Edinburgh in 1956. Problems arising out of the diversions of water from one watershed to another have also been studied.

New schemes for hydro-electric developments, such as those now contemplated in Wales, are carefully examined by the various departments interested and by the Nature Conservancy. When the scheme is finally submitted to Parliament, such bodies as the Council for the Preservation of Rural England and of Wales, and the National Trust for the preservation of places of historical interest and natural beauty, are entitled to petition Parliament itself, and in fact do so. They are then able, through their advocates and representatives, to criticize the proposals in detail and to ask for such modifications as they can persuade the independent and impartial Committees of each House to make before Parliament itself finally decides the matter.

On the other side of the world, in the Philippine Islands, there was recently a striking example of the kind of co-operation between engineers and independent biological experts which the 
Union would like to make general. Advantage was taken of the assembly of the International Pacific Science Congress at Manila to arrange with the Government and the Power Corporation, for a group of scientists to visit the site of some important works proposed to be constructed at Ambuklao. As a result of their survey, they were able to make a number of valuable comments and suggestions which were sympathetically entertained by the Corporation. It is encouraging to record that the arrangement was brought about by the good offices of Mr. H. J. Coolidge, as a Vice-President of the Union of which he is so strong a supporter, and that the visiting scientists included Professor Roger Heim, the Union's President.

In every country there should now be established a recognized body of experts, of high standing and repute and financially independent of the constructing authorities. This body would be consulted in all hydro-electric propositions and consulted before, not after, the project has reached any advanced stage or taken too definite a shape. The variety of the scientific problems is so great that a wide range of knowledge must be brought to bear upon them and for that reason pedologists, ecologists, phytologists and many other specialists should, in the Union's view, be included.

If the engineers, whose skill in conquering the difficulties presented by Nature is so great and who are themselves men of scientific outlook, were able more generally to appreciate the fundamental importance of the biological consequences of their interference with the natural order, they and those who employ them would be the better able and, we may hope, more ready to take an enlightened view of the need to conserve as much of our natural heritage as possible. By co-operation much could be spared, much reinstated and perhaps, here and there, there might be a gain of something new and ecologically valuable.

Note.-The above article first appeared in Science et Nature, a magazine published under the authority of the National Muscum of Natural History, Paris. It is republished with permission. 